An investigation of the role played by frequency and uncertainty in hotel outsourcing decisions

Dawne Lamminmaki

Department of Accounting, Finance and Economics

Gold Coast Campus - Griffith University

Queensland 4222, Australia

d.lamminmaki@griffith.edu.au

Phone: + 61 (0) 755528791

Fax: + $61(0) 755528553$ 


\title{
An investigation of the role played by frequency and uncertainty in hotel outsourcing decisions
}

\begin{abstract}
This paper draws on Transaction Cost Economics (TCE) theory (Coase, 1937; Williamson, 1985, 1988, 1999) to examine hotel outsourcing. The study focuses on the uncertainty and frequency attributes, two of three activity attributes that TCE theorists see as affecting the propensity to outsource. Findings relating to the third TCE activity attribute, asset specificity, are reported in Lamminmaki (2005). Qualitative data was collected by interviewing fifteen senior managers in large hotels. While several observations made supported the frequency tenet of TCE, which holds that frequently and extensively conducted activities will be outsourced to a low extent, two specific departures were noted. These departures resulted in the proposition of an extension to the TCE frequency tenet. The TCE doctrine also holds that uncertain activities will be outsourced to a low extent. Again, although observations made supported this view, one specific observation that contradicted the theory was noted.
\end{abstract}

Keywords: Hotels, Outsourcing, Transaction cost economics, Uncertainty, Frequency 


\section{An investigation of the role played by frequency and uncertainty in hotel outsourcing decisions}

\section{Introduction}

Outsourcing appears to have become a more prevalent facet of hotel management in recent years. This development appears to have triggered increased empirical research of hotel outsourcing (Paraskevas and Buhalis, 2002; Espino-Rodríguez and PadrónRobaina 2004, 2005; Espino-Rodríguez and Gil-Padilla, 2005; Lam and Han, 2005; Lamminmaki, 2005, 2007). This research interest can be attributed to the widely accepted antecedental significance that organisational configuration carries for corporate performance (Milgrom and Roberts, 1992).

This paper can be seen as complementing Lamminmaki’s (2005) qualitative study that appraised the role played by asset specificity in determining hotel outsourcing. Asset specificity is a concept first referred to by Coase (1937) and is now one of the three generally accepted fundamental tenets that comprise Transaction Cost Economics (TCE). The other two tenets concern frequency and uncertainty (Williamson, 1979, 1985, 1996), and it is these two tenets that lie as the focus of this study. TCE is a widely-applied theory that proposes that an organisation will organise itself in a manner that is conditioned by the underlying nature of the activities it pursues. The purpose of the study reported herein is to qualitatively examine the validity and 
applicability of the TCE frequency and uncertainty tenets in the context of hotel outsourcing.

TCE's frequency theory proposes that the more extensively an activity is performed, the more likely it will be insourced due to the economies of scale that can be achieved inhouse. TCE's uncertainty proposition holds that the greater the uncertainty associated with the undertaking of an activity, the more difficult contracting becomes. This contracting problem signifies that uncertain activities will tend to be insourced in an attempt to avoid opportunistic behaviour that may result from a deficient outsourcing contract (Birnberg, 1998).

The remainder of the paper is organised as follows. The next section provides a literary context for the study by describing the nature of the frequency and uncertainty attributes and also prior empirical research that has drawn on and examined these constructs in conceptualising observed outsourcing behaviour. The study's research method is then described followed by a description of the study's findings. The paper concludes with an overview of the study's most pertinent findings and its major limitations.

\section{Literary context of the study}

Although TCE has been widely drawn on in prior research (see for example, Williamson, 1979, 1985; Milgrom and Roberts, 1992; Birnberg, 1998; Seal et al., 1999; Widener and Selto, 1999, van der Meer-Kooistra and Vosselman, 2000; Spekle, 2001; Vosselman, 2002; Langfield-Smith and Smith, 2003; Sartorius and Kirsten, 
2005), other than Espino-Rodríguez and Padrón-Robaina 2005 and Lamminmaki (2005, 2007), no other TCE examinations of outsourcing practice have been found in the hospitality literature. Recognition of the paucity of prior TCE motivated research in the hospitality management domain was instrumental in motivating the conduct of this study.

There has been extensive commentary on TCE, and the frequency, uncertainty and asset specificity activity attributes in the literature. Despite this, Carter and Hodgson's review of TCE studies (2006) revealed a lack of attention directed to the frequency attribute. Frequency refers to the repetitiveness (and volume) of similar transactions. When referring to this notion, Colbert and Spicer (1995) use the term "extent” in order to capture both “frequency” and "volume”. As already noted, TCE theory holds that the greater the extent of a transaction (i.e., large and recurring transactions), the more likely the transaction will be internally managed due to the production economies that can be obtained. Within a single hotel, there is considerable variability with respect to the frequency with which a range of activities are conducted, eg, compare dishwasher maintenance (low frequency) to managing check outs (high frequency). Further, hotel size and occupancy levels affect the degree to which many activities will be conducted such as room cleaning, laundry, or food and beverage. Consequently, an assessment of the importance of the frequency dimension of TCE seems particularly pertinent to understanding hotel outsourcing practice.

This view of "frequency" as a continuous variable departs from the perspective taken by some who have viewed it in dichotomous terms as the distinction between onetime and recurrent exchange. Resulting from this narrow definition, many studies may 
have ignored frequency, deeming it irrelevant if their study relates to recurrent exchange (John and Weitz, 1988 and Klein et al., 1990).

Exceptions to the view that high frequency activities will not be outsourced appear to occur when the activity in question is somewhat specialised. Specialist suppliers can achieve a size and degree of specialisation that enables them to conduct activities more effectively and efficiently than when they are conducted inhouse. Information technology and human resource management represent two activity areas where inhouse providers can experience difficulty competing with specialist suppliers (Domberger, 1998, Kakabadse and Kakabadse 2000). Reservation system software management is an activity that has been widely outsourced in hotels for many years (Anthes, 1996) and it is notable that Holiday Inn's hotel reservation business was set up to serve the entire hospitality market (Venkatraman, 1997).

Uncertainty can be seen as constituting a two dimensional construct, as the conduct of an activity can involve varying degrees of environmental as well as behavioural uncertainty (Williamson, 1975, 1979; Anderson, 1985; John and Weitz, 1988, and Widener and Selto, 1999). An activity’s environmental context can be uncertain for a variety of reasons. It could be that demand for a service (eg., room sales) is volatile and unpredictable. This makes it difficult to specify how much the activities entailed in supporting the service's provision will be required (eg., housekeeping), thus making contracting difficult. Behavioural uncertainty relates to the difficulty of appraising the quality of performance associated with the conduct of an activity. If it is difficult to monitor and control performance, or to know whether a task has been 
adequately conducted, subcontractor opportunism may result. This can be likened to the notion of goal incongruence discussed in agency theory (Eisenhardt, 1989).

Both Anderson (1985) and Milgrom and Roberts (1992) elaborate on the notion of complexity which can be seen as closely associated with uncertainty. Heightened levels of complexity signify greater difficulty in identifying performance standards. Milgrom and Roberts also note that uncertainty increases as the length of time required to complete a transaction increases. They summarise the implications of uncertainty in the following manner:

"Uncertainty about the conditions that will prevail when a contract is being executed together with complexity of the task, make it impossible, or at least uneconomical, to determine in advance what should be done in every possible contingency, so the contract that is written will generally be less determinate than in a simpler setting. Rather than specifying how much of what is to be delivered when, the contract may specify who has the right to make which decisions and within what limits” (1992, p.32).

A fundamental assumption of TCE is that individuals always act in their own interest. Domberger (1998) refers to implicit and explicit costs in an elaboration of this assumption. Implicit costs relate to the incompleteness of contracts which can trigger expensive negotiation costs and opportunistic behaviour. If attempting to outsource an intrinsically uncertain activity, due to the difficulty of foreseeing all potential eventualities, contract negotiation time can be significant and costly. If such an activity is outsourced, there is a greater likelihood of unexpected events unfolding and “contractual hazards” can emerge which may open the potential for opportunistic 
behaviour. To avoid the problems (costs) associated with incomplete contracting, TCE holds that in the presence of greater uncertainty, there is a greater likelihood for transactions to be internally mediated.

There is a significant amount of empirical research that draws on TCE theory to examine organisational form. Much of this work has focused exclusively on the asset specificity construct (eg., Monteverde and Teece, 1982; Palay, 1984; Colbert and Spicer, 1995; Deegan, 1997; Nickerson et al., 2001), an emphasis that has been widely acknowledged (Williamson, 1991; Widener and Selto, 1999; David and Han, 2004; Carter and Hodgson, 2006). Empirical studies that have examined the role played by all three TCE attributes include Levy (1985), John and Weitz (1988), Maltz (1994), Widener and Selto (1999), and Lamminmaki (2007) and interactions between the three attributes have been examined by Gatignon and Andersson (1988), Pilling et al. (1994), Widener and Selto (1999) and Vosselman (2002).

Carter and Hodgson (2006) reviewed the most influential and highly cited TCE empirical studies and concluded that despite TCE being "one of the most prominent and influential developments in the social sciences” (p. 461), the findings are mixed. Of the 27 studies reviewed, asset specificity was the main attribute appraised, and in most cases frequency was not considered. To ignore frequency, uncertainty or asset specificity signifies a partial investigation of the TCE framework, and signifies that the results are inconclusive and limiting (Carter and Hodgson, 2006). Similarly, a review by David and Han (2004) of 63 studies found that asset specificity was the main attribute appraised. This predilection to emphasise the role of asset specificity 
underscores the contribution of the study reported herein, due to its focus on frequency and uncertainty.

The findings of studies that have examined the relative significance of the uncertainty and frequency attributes are also somewhat equivocal (eg., Anderson and Schmittlein, 1984; , Anderson, 1985; John and Weitz, 1988; Maltz, 1994; Widener and Selto, 1999; Lamminmaki, 2007). Widener and Selto (1999), using regression analysis, found support for their hypothesis relating to asset specificity, mixed support for frequency, and no support for uncertainty. Lamminmaki (2007), also using regression analysis, found limited but mixed support for asset specificity and uncertainty, and limited support for frequency. Anderson (1985) and Anderson and Schmittlein (1984) had mixed findings, with no support for frequency. Uncertainty has frequently been considered in the context of asset specificity, and it has been argued that only if there is asset specificity will uncertainty have an affect on organisational form (Williamson, 1979; David and Han, 2004; Carter and Hodgson, 2006). Despite this, there are cases of the role of uncertainty being examined in isolation from asset specificity and frequency (Noordewier et al, 1990 and Osborn and Baughn, 1990).

In acknowledging the lack of prior work providing support for the TCE uncertainty tenet, Widener and Selto (1999) specifically comment on the problem of operationalising the uncertainty construct. In light of this, they recommend the application of qualitative-based research as a more promising means for furthering our appreciation of uncertainty's significance. In light of the mixed findings to date, the qualitative approach taken in this study appears to represent an appropriate 
method when seeking to shed further light on the nature of the role played by activity frequency and uncertainty in hotel outsourcing.

\section{Research method}

Fifteen on site interviews with managers representing eleven large South East Queensland (Australia) hotels have been conducted. Nine interviewees were financial controllers, three were general managers, two were Food and Beverage (F\&B) managers, and one was a project engineer. An overview of the interviewees and the hotels they represent is provided in Table 1 . The Table's first column provides the referencing system used to identify each interviewee. This coding scheme has been drawn upon in the following section when citing a specific interviewee's comments. Interviews were conducted with more than one interviewee in Hotels 1 and 5. These interviewees have been differentiated by using an abbreviation of their title, eg., "FC” (Financial Controller).

\section{Insert Table 1 about here}

The interviews ranged between one to two and a half hours. A flexible method of interviewing was adopted so that interviewees could discuss relevant reasons for outsourcing, without being prompted in any particular theoretical direction or towards discussing any particular hotel activity. Depending on what course the interview took, probes relating to the theoretical constructs were introduced by the interviewer in the latter stages of the interview. With the exception of the first interview, all interviews were tape-recorded and subsequently transcribed. 
As most interviewees had more than ten years experience, commentaries provided drew on their experience with outsourcing over the course of their hotel career, rather than being limited to experience with their current employer. The interviews were conducted in a fairly concentrated geographical region. This provided an opportunity to corroborate some of the data collected, as many of the interviewees had a good knowledge of what was being outsourced in some of the other hotels where interview data was collected.

\section{Field study findings}

The objective of the field study interviews was to uncover outsourcing arrangements as well as attitudes towards factors affecting what activities can be outsourced, and to then determine whether the observations made provide support for TCE's theory with respect to the frequency and uncertainty attributes. The following propositions are posited in a manner consistent with TCE theory:

Proposition 1: Outsourcing will be higher for activities involving a relatively small amount of work.

Proposition 2: Outsourcing will be higher for activities involving low degrees of uncertainty.

In this section, findings relating to the frequency attribute are presented first. This is followed by findings pertaining to the uncertainty activity attribute. 


\subsection{Appraisal of the frequency attribute}

It was evident from the interviewee comments that the frequency attribute is pertinent to many of the outsourcing decisions taken by the hotels. Interviewee 4 saw hotel size as the biggest factor causing hotels to insource their food and beverage activities. Similarly, the Financial Controller (FC) in Hotel 9 noted that as volume increases, after a certain point outsourcing is no longer justifiable. Hotel activities that he cited to illustrate his point included housekeeping, payroll, and gardening. FCa in Hotel 1 noted the significance of the size of some specialist suppliers in commenting on the frequency issue. He noted that the typical subcontractor:

“... pride themselves on bringing to the organisation something to the equation that you cannot do all that well yourself. So in the financial world, a fine example of outsourcing is the managing of foreign exchange. Organisations cannot manage their own foreign exchange very well. Why? They are exposed. A bank can do it because they have hundreds of international transactions”.

The remaining findings relating to TCE's "frequency theory” have been organised according to three broad activity classifications: food and beverage (F\&B), administrative and professional activities, and cleaning and maintenance services. The "frequency" related observations conclude by noting specific observations that conflict with TCE's frequency expectation, and also an attempt to extend earlier theorising on the frequency attribute by considering it in the context of volatility. 
In all of the hotels visited, the banqueting service was conducted inhouse. The primary reason given for this arrangement concerned the need to maintain sufficient control. This approach is consistent with the observations of Brumback (1992) and Hemmington and King (2000) who concluded that most hotels prefer to retain control of banqueting. In Hotel 1, however, FCa felt that the main reason banquets were not outsourced was because: "We are large enough to be able to do that ourselves".

Liberson (1995) and Alva (1995) discuss the benefits of outsourcing pre-prepared ingredients. Many of the hotels interviewed had moved to outsourcing pre-prepared ingredients and this decision appears to have been motivated from a mass-production (frequency) perspective. Within Hotel 3’s group, hotels were developing centralised kitchens in which the majority of foods are pre-prepared:

“The kitchens will not be like our kitchens, but will be a reconstituted kitchen. .... so you will see less chefs, but the product is always the same”.

The connection between specialisation and frequency which has already been noted is again apparent in the following two comments provided by the FC in Hotel 2 in connection with bread and chocolate production. The degree to which these tasks were perceived as specialised appears related to their volume levels:

“To have a kitchen set up and a chef to make bread to the quality we want, we cannot justify on the volume”.

"Chocolates is a specialised skill. We could set up a chef and give him space but if he was working a 40 hour week, he would make more chocolates than 
we would ever have a use for. What skills do we need, and have we got the volume to justify having that person inhouse?’.

The General Manager (GM) in hotel 3 acknowledged a quest for securing economies of scale by outsourcing pre-prepared ingredients and felt that a shortage of appropriate suppliers had inhibited their degree of outsourcing. He commented:

"We cannot get a good one yet .... the day we can get a good one, we will (outsource it)”.

Further support for TCE's frequency tenet was noted in connection with pastry production. It was noted that pastry production was conducted inhouse in the largest hotel interviewed (Hotel 1) and outsourced in most others. Pastry volume was consistently referred to as the factor driving the decision to outsource. Pastry production was seen to be relatively specialised and it was noted that pastry chefs can command high salaries. It was evident that engaging a full-time pastry chef can only be justified where pastry production is sufficient to occupy the chef full time. An innovative way to manage the pastry volume issue was described by Hotel 4's Food and Beverage (F\&B) manager. This hotel had recognised the problem of its normal activities giving rise to insufficient demand for pastries. As a result, the hotel had opened a retail pastry shop. This managed the volume issue by channelling the excess supply of pastries into retail sales.

With respect to administrative and professional activities, Hotel 11 outsourced its computer support when its employee responsible for computer support resigned. The FC in this hotel rationalised this changed arrangement by noting that there was 
insufficient justification for a full time position, and that by sub-contracting, the hotel could get the amount of expert service it needed for about a quarter of the cost.

Although the bulk of the interviewees were reluctant to outsource the management of marketing strategy, FCa in Hotel 1 described how aspects of strategy development had been outsourced. Hotel 8's GM commented that smaller hotels may outsource this type of activity as smaller hotels may well not have the capacity to manage them inhouse. Like the food and beverage examples above (eg, chocolate, bread, pastry), if the degree to which the activity is conducted is insufficient to warrant the hiring of a full time person, outsourcing is a more economical option.

It was found that customer satisfaction research, a particular marketing activity, was generally outsourced. Hotel 3's decision to outsource customer satisfaction research appeared to be motivated primarily by frequency and specialist supplier issues. Related to this, the FC in Hotel 2 commented:

“They (the research company) have the right skills to do it and it would not be cost effective to do it (in house). If we hired one or two bodies we would still not have the appropriate cross section of skills to handle that work”.

Hotel 3's GM noted that the main reason for outsourcing customer satisfaction research was the need to achieve independence. However, he also noted other reasons including cost, sophistication and speed:

“Their technical ability to do the job quickly for seventy hotels in Australia. It was not very sophisticated before this. This offered sophistication for little money”. 
The frequency attribute is also apparent in comments made by FCa in Hotel 1 in connection with merger and acquisition analysis:

"If we do not have these skills, I would quickly have to avail myself of a team of people. You certainly would not put those people on because you could not afford them on a regular basis.... If we were Hilton USA, where they are forever on an acquisition path, they have a mergers and acquisition team in place. I don't, I do it sporadically and therefore .... subcontract out to someone else”.

With respect to cleaning and maintenance activities, it was found that most hotels outsourced carpet and window cleaning due to the economies of scale that a supplier can achieve. It was widely claimed that cleaners can specialise and offer a superior service to what would be achieved if the activity were to be conducted inhouse. Despite this, it was noted that all hotels maintained an inhouse capacity to complete spontaneously arising, one-off, small jobs.

Conflicting effects with respect to the implications of uncertainty and frequency attributes were apparent from comments made by the F\&B manager in Hotel 4. This manager felt it would be easy to outsource F\&B cleaning because the tasks required are straight forward and easy to contract for (i.e., low uncertainty). However, he believed that as the hotel had a large inhouse housekeeping department, it was appropriate to continue with the operations being managed inhouse. In this case, it appeared the scale economies associated with managing the housekeeping function inhouse were sufficient to outweigh the low transactions costs that would arise if the service was outsourced. 
At the time of the interview, Hotel 8 outsourced approximately half of its linen ownership to a laundry specialist, and was planning to outsource the remainder in the subsequent six months. Cost savings due to the additional economies of scale that could be reaped by the laundry specialist appear to have motivated this decision. It was ascertained that the savings were significant because the laundry outsourcer could buy in bulk. This hotel appeared unusual in this arrangement, however, as linen quality concerns commented on by most of the interviewees, were preventing them considering outsourcing linen ownership to a laundry specialist. Although the frequency notion was driving the outsourcing of laundry ownership in Hotel 8's example, most interviewees insourced laundry ownership due to the risk that suppliers would not replace linen when needed. This concern over the possibility of a damaged image resulting from inadequately cleaned linen relates to asset specificity’s brand capital issue. This idea is explored further in Lamminmaki (2005).

Two observations that represent strong refutations of the frequency TCE tenet were made. The first concerns the fact that being part of a large hotel chain appears to carry two conflicting "frequency" effects. Firstly, a hotel that is part of a group benefits from the ability to share in group support services. For example, Hotel 11 moved to insourcing gardening as they were able to share a full time gardener with a sister hotel. This observation supports the TCE frequency proposition. The second effect concerns the fact that all interviewees in hotels that were part of groups (eg. Hotels 1, $2,3,6,7$, and 11), referred to enhanced purchasing power from being part of a group. This highlights how greater frequency associated with being part of a group, signifies cheaper outsourcing opportunities. As size increases purchasing power, increased size 
signifies a discounted cost of outsourcing. This second frequency perspective arising in a hotel chain clearly counters the conventional TCE prescription.

A second observation countering the TCE frequency tenet was made in Hotel 8, where the GM felt that garden maintenance was worth outsourcing if the grounds were big enough. He commented:

“Once you start changing 10-50 plants every month, then you start to outsource”.

This observation suggests that where frequency of a non-specialized activity is very low, it is uneconomic to outsource. In this gardening example, it appears that if less than 10 plants are being replaced per month, the size of the activity is insufficient to make it worthwhile for a subcontractor becoming involved. In this type of situation, it appears appropriate to permanently employ a general handyman. If the jobs completed by the handyman comprised 20 activities which could be outsourced independently of one another, then the hotel is saving contracting with 20 different parties and the transportation costs associated with 20 visits by 20 separate subcontractors. Also, in a similar vein, it was noted earlier that small one-off cleaning and maintenance activities tend to be conducted in house.

Following these two observed departures from the TCE frequency tenet, the TCE model can be revised along the lines outlined in Table 2 .

\section{Insert Table 2 about here}


Another particular aspect of frequency relates to its relationship to demand volatility. Hotel 9's FC discussed room occupancy volatility. He explained that room occupancy volatility results in additional costs due to the management and training of casual labour which has a high turnover rate. He felt that if occupancy levels are volatile and unpredictable, it makes sense to outsource occupancy related activities (eg. housekeeping). In effect, the hotel was outsourcing the problem of volatility management to the supplier. Due to its size, it appears a speciality supplier is more capable of managing this volatility problem, i.e., it has greater scope to smooth peak demand periods across a larger work force.

Although this aspect of volatility may appear related to environmental uncertainty discussed in the next section, the connection between volatility and size of the subcontractor relative to a hotel has resulted in its consideration in the context of the "frequency" examination. The key dimension of frequency here is the cumulative size of the contracts undertaken by a sub-contractor. As this cumulative size increases, so the sub-contractor becomes better able to manage high levels of uncertainty and unpredictability, hence the existence of a particular relationship between size and uncertainty management. Contrasting with the conventional TCE prescription of high uncertainty resulting in decreased outsourcing, the rationale just provided outlines a case of sub-contractors increasing in size in order to manage high uncertainty (ie., high uncertainty resulting in more outsourcing).

Another example of a connection between frequency and volatility relates to the sourcing of certain food ingredients. If many hotels pool their volatile purchasing patterns through one agent, the agent may be more capable of managing the volatility. 
For example, if certain foods have high price variability, it may be that a specialist supplier can smooth prices through bulk buying and buying from around the world. FCa in Hotel 1 commented:

"It depends on the nature of the organisation you could outsource to, if that organisation was capable of smoothing out the volatility for you. Let's say it was a highly volatile area like seafood. If that organisation had an incredible buying power throughout the world, which you at (the hotel) could not achieve through your 2-3 people in purchasing, volatility would therefore drop if you were to outsource.... We can fly you in the abalone from around the world in 24 hours and it will be fresh .... and we will still do it at the price because it would do two things.... It would make sure that you meet customer demand. It would lock into profit margins by you being able to lock in certain prices which you can negotiate with them, and that would be great. So uncertainty (or rather volatility) in some situations may actually drive you to outsource”.

In summary, it appears appropriate to consider "volatility" in the context of frequency, as the relative size and specialization of subcontractors may equip them to manage the volatility problem. This perspective does not appear to have been recognised in the TCE literature.

\subsection{Appraisal of the uncertainty attribute}

As already discussed, uncertainty relates to contract incompleteness, and according to TCE theory, uncertain activities are difficult to contract for and will therefore tend to be insourced to avoid the risk of opportunistic behaviour. The findings relating to the 
uncertainty attribute have been structured by first considering comments pertaining to F\&B activities, and then observations relating to non-F\&B activities. The section concludes with an observation that counters the TCE uncertainty tenet.

When asked if it is difficult to outsource any activities due to their instability, unpredictability or complexity, most interviewees immediately started discussing “F\&B" management issues. It appears the main concern revolves around a problem of maintaining sufficient control, as F\&B was widely seen to represent an activity that is “too important to outsource”. As control and the issue of uncertain contracting are so inextricably linked, many of the insights concerning control provided by the interviewees appear worthy of note.

Hotel 8's GM saw F\&B as unstable because of the many activities involved, i.e., purchasing, receiving, storing, preparing, and the logistics of preparing food and assembling meals. He saw the production line to be long, noted quality as being key, and recognised that many things can go wrong. Consequently, he did not wish to outsource $F \& B$ as it warranted close control. He felt that no contract could provide the same control as managing $F \& B$ inhouse.

Hotel 9's FC expressed a similar view:

"Potentially you can have a lot of very upset hotel guests because they do not get their breakfast on time, it is not up to scratch, and so on. Although you can try and contract in, if things go wrong, you are not able to do whatever you see fit to manage the situation, and have to rely on the subcontractor to behave appropriately, or have the hassle of enforcing the contract.... F\&B in general is 
just a huge hassle. It is labour intensive, you get the biggest problems out of food and beverage, and it is a high cost operation.... There is lots of activity, you spend lots of time administering $\mathrm{F} \& \mathrm{~B}$, and at the end your profit margins are next to nothing”.

This view that $F \& B$ is not only logistically problematical but also generates low profits also appeared to be widely held. Despite all of these negatives, the interviewees saw F\&B as too important to contract out. The following perspective provided by hotel 6's FC typify what appear to be the generally held views of the sample of managers:

"The view from a lot of hotel companies is that F\&B are a necessary evil, they do not make you a lot of money, but it is a service that you have to have”.

With respect to other activities, the concerns raised by hotels not wishing to outsource could frequently be traced to a notion of behavioural uncertainty, i.e., the inability or difficulty in evaluating performance. Although it has been said that opportunism is as likely to occur within organisations, as it is between organisations (Domberger, 1998), from comments made, it appears that most of the managers felt that if a hotel is not satisfied with performance, it is easier to manage a change in the behaviour of an inhouse employee, than it is to renegotiate with a supplier.

Different views were expressed by interviewees with respect to what could be outsourced. Garden maintenance was described by Hotels 5 and 12 as being difficult to outsource due to the problems of ensuring the work is completed satisfactorily 
(behavioural uncertainty). By way of contrast, in Hotel 1 it was felt appropriate to outsource garden maintenance as it was viewed as "not their core business".

Other areas described as unstable and difficult to contract for included public area cleaning and room cleaning. Hotel 5's GM was considering outsourcing public area cleaning, but recognised it as constituting a difficult activity to contract for due to its intrinsic variability. He noted that it was difficult to set prices and prepare contract specifications as it was unclear how much cleaning would be required:

"How can I write a specification when the amount of use of a particular area varies, and you cannot just do it by the number of guests who come through, because some guests are dirtier than others. .... A bunch of accountants are a lot cleaner than the miners. When the miners come in they make a mess”.

By way of contrast, Hotel 9's FC saw public area cleaning as relatively stable and that it was an easy activity to contract for. This hotel had previously contracted out public area cleaning, but it appeared that due to TCE's “frequency" rationale, it had reverted to being managed inhouse. It was noteworthy that due to the different nature of events and activities undertaken by hotels, what might be uncertain and unstable in one hotel is not necessarily uncertain and unstable in another hotel.

One commentary provided by Hotel 8's GM counters the TCE uncertainty tenet. He said he preferred to outsource where there is specialised work or specialised equipment:

"Where we want to shy away is where you have to constantly upgrade your equipment, constantly retrain the people. We would rather give it to you, a 3 
year contract, we know the costs we are up against, and we know we get it done”.

Constantly having to retrain and upgrade due to technological advancement highlights behavioural as well as environmental uncertainty. The behavioural uncertainty arises because in a field subject to technological change, the hotel's lack of expertise may signify it is not well equipped to monitor a specialist's performance. In light of this, the TCE model would lead us to expect insourcing of activities subject to technological change. Yet it appears in this example, it is the activity's instability that results in outsourcing. This observation suggests that fast evolving fields can give rise to increased outsourcing.

As a summary of the study's most significant observations, Table 3 provides an overview of the interviewee comments and observations made that either support or contradict the TCE frequency proposition. This overview has been structured according to the activities relating to each comment or observation cited. In a similar manner, Table 4 provides an overview of pertinent comments and observations relating to the TCE uncertainty proposition. In both these tables, observations that support the TCE theory are in plain type and observations contradicting the theory are presented in italics.

Insert Table 3 about here

\section{Insert Table 4 about here}




\section{Discussion and conclusion}

\subsection{Synthesis and discussion of main findings}

This study has examined the pertinence of the TCE attributes of frequency and uncertainty to hotel outsourcing decisions. Numerous observations supportive of the TCE model have been noted, and the study's overall conclusion is that the TCE tenets concerning frequency and uncertainty represent useful factors to consider when attempting to understand hotel outsourcing behaviour.

Two departures to the TCE's frequency tenet have been noted and extensions to the TCE theory have been provided in Table 2. It was noted that hotels that are part of a group may be more likely to outsource due to the additional purchasing power secured by larger entities. Membership of a group provides greater bargaining power, a factor that can facilitate an outsourcing contract being negotiated. Secondly, if the volume of work associated with a particular activity is very low (eg. gardening or maintenance), it may be uneconomic to outsource. Both of these observations counter the TCE model with respect to frequency.

The lack of attention directed to frequency in prior empirical studies may be the result of a view that the frequency theorem is sufficiently clear cut and economically rational to be unworthy of examination. The findings and discussion provided herein, however, demonstrate that the frequency dimension is more complex than a simple “economies of scale” notion. In Lamminmaki’s (2007) quantitative analysis of factors affecting hotel outsourcing, of the four dependant variables appraised (outsourcing in general, F\&B, laundry, general maintenance and housekeeping), only the outsourcing of laundry and housekeeping findings supported the TCE frequency 
theorem. The findings described herein suggest that managers' reluctance to lose control over F\&B provision may well lie behind Lamminmaki’s failure to find an association between frequency and F\&B outsourcing.

It has also been found that subcontractors might be better equipped to manage demand volatility. This is because the subcontractor can specialise and spread demand volatility across a larger workforce. This is viewed as an extension to the TCE model, as no prior discussion of the particular impact that high volatility can have on the frequency tenet has been found. Parmigiani (2007) discussed demand uncertainty, describing it as a type of environmental uncertainty. In contrast to the view above, Parmigiani (2007) believed the difficulty in forecasting and scheduling would make it difficult to outsource, however she failed to provide support for her hypothesis.

This study has also provided many observations pertinent to both environmental and behavioural uncertainty. Some of the interviewees saw difficulties outsourcing garden maintenance, public area cleaning, and room cleaning due to their perceived uncertainty. These findings all support the TCE model

One observation contradicted the TCE uncertainty tenet. One manager saw technological change (a dimension of uncertainty) as motivating a desire to outsource. It appeared he preferred not to have to worry about the technological change. This suggests that in some situations a supplier might be better placed to manage uncertainty, eg., where equipment needs to be continually upgraded. In these situations uncertainty can act as a motivation and not a deterrent to outsourcing. This is consistent with an observation made by Balakrishnan and Wernerfelt (1986). In 
light of this, it is particularly noteworthy that the empirical findings with respect to whether technological uncertainty will lead to outsourcing have been mixed (Mahoney, 1992, Williamson, 1985, Rindfleisch and Heide, 1997, Parmigiani, 2007).

\subsection{Implications of findings on practice}

There are several ways in which this study has the potential to inform practitioners' management of outsourcing. The following recommendations and summary comments are made:

1) Although no theory is all encompassing, TCE's frequency and uncertainty tenets represent useful perspectives that can be drawn upon when considering outsourcing an activity. A manager would be well-advised to consider the frequency, uncertainty and asset specificity of an activity prior to committing to an outsourcing arrangement.

2) In relation to the frequency attribute and outsourcing, this study has provided several novel perspectives that appear worthy of consideration by practitioners:

a. If an operating entity is part of a larger group, a manager should consider the group's purchasing power that can be realised by consolidating their demands when negotiating with a supplier.

b. If an entity has insufficient demand to warrant insourcing a particular activity, but would like to do so in order to maintain control, insourcing can be achieved by: 
i. offering the surplus capacity production to the market place, in a manner similar to the retail pastry shop example,

ii. sharing the services with a sister organisation, in a manner similar to the garden maintenance example.

c. If an entity experiences demand volatility, it may like to consider outsourcing to a specialist supplier, as that supplier may be better able to spread the volatility across a larger workforce.

3) In relation to the uncertainty attribute, an activity that is uncertain in one organisation is not necessarily uncertain in another. This signifies that each organisation should assess its own particular environment when determining whether outsourcing is appropriate, and not rely on observations of what outsourcing practices are being adopted by similar organisations.

4) Although much resistance to outsourcing food and beverage was evident in the sample investigated, one GM expressed a strongly held view that Australian hotels are lagging behind other Western countries in terms of F\&B outsourcing. This suggests greater scope for successful F\&B outsourcing in Australian hotels.

\subsection{Limitations of the study}

Like all fieldwork, this study suffers from the normal shortcomings associated with qualitative research, including the potential for interviewer bias and the lack of generalisability resulting from the small sample size. Given the complex nature of TCE however, conducting interviews was deemed useful as "With qualitative data one can preserve chronological flow, see precisely which events led to which consequences, and derive fruitful explanations” (Miles and Huberman, 1994, p.1). 
Abernethy and Brownell (1999) note that although refining or extending well established theory can be gained by a focus on breadth, a lack of depth means a lack of richness and this can inhibit our ability to build theory. In light of these comments, it is felt that the methodology employed has provided the basis for a richer understanding of the role played by TCE's frequency and uncertainty activity attributes in hotel outsourcing decisions. Further, the study can be seen as a response to Widener and Selto’s (1999) call for qualitative research on TCE, so that "richer explanations of conditions leading to decisions to internalise or outsource” (p. 68) can be gained. 


\section{References}

Abernethy, MA \& Brownell, P 1999, "The role of budgets in organizations facing strategic change: an exploratory study”, Accounting, Organizations and Society, vol 24 No 3, pp. 189-204.

Alva, M 1995, 'Who cooked this stuff?’, Restaurant-Business, vol. 94, no. 2, pp. 3445.

Anderson, E. 1985, 'The sales person as outside agent or employee: a transaction cost analysis, Marketing Science, vol 4, no. 3, pp. $234-254$.

Anderson, E \& Schmittlein, DC 1984, 'Integration of the sales force: an empirical examination', RAND Journal of Economics, vol. 15 (Autumn), pp. 385-395.

Anthes, G 1996, ‘Who’s got your code?’, Computerworld, vol. 30, no. 49, pp. 53-59.

Balakrishnan, S \& Wernerfelt, B 1986, 'Technical change, competition and vertical integration, Strategic Management Journal, vol. 7, no. 4, pp. 347-359.

Birnberg, JG 1998, 'Control in interfirm co-operative relationships', Journal of Management Studies, vol. 35, no. 4, pp. 421-428.

Brumback, N 1992, ‘The Inn Crowd’. Restaurant Business, vol. 91, no. 9, pp. 68-76.

Carter, R \& Hodgson M 2006, 'The impact of empirical tests of transaction cost economics on the debate on the nature of the firm', Strategic Management Journal, vol. 27, pp. 461-476.

Coase, R 1937. The Nature of the Firm. Economica N.S 4, 386-405.

Colbert, G \& Spicer B 1995, 'A Multi-case investigation of a theory of the transfer pricing process’, Accounting Organizations and Society, vol. 20, no. 6, pp. 423-456.

David, RJ \& Han, S 2004, 'A systematic assessment of the empirical support for transaction cost economics’, Strategic Management Journal, vol. 25, pp. 39-58.

Deegan, C 1997, 'Efficient management remuneration plan design: A consideration of specific human capital investments’, Accounting and Finance, vol. 37, no. 1, pp. 140 .

Domberger, S 1998, The Contracting Organization: A Strategic Guide to Outsourcing, Oxford University Press, Oxford.

Eisenhardt, KM 1989, 'Agency Theory: An Assessment and Review', Academy of Management Review, vol. 14, no. 1, pp. 57-74.

Espino-Rodríguez, T \& Gil-Padilla, A 2005, 'The relationship between leisure outsourcing and specificity: performance and management perception in hotels in the 
Canary Islands', Journal of Hospitality \& Tourism Research, vol. 29, no. 3, pp. 396418.

Espino-Rodríguez, T \& Padrón-Robaina, V 2004, 'Outsourcing and its impact on operational objectives and performance: a study of hotels in the Canary Islands', International Journal of Hospitality Management, vol. 23, no. 3, pp. 287-306.

Espino-Rodríguez, T \& Padrón-Robaina, V 2005, 'A resource-based view of outsourcing and its implications for organizational performance in the hotel sector', Tourism Management, vol. 26, no. 5, pp. 707-721.

Gatignon, H \& Anderson, E 1988, ‘The multinational corporation's degree of control over foreign subsidiaries: An empirical test of a transaction cost explanation', Journal of Law, Economics and Organization, vol. 4, fall, pp. 305-335.

Hemmington, N \& King, C 2000, Key dimensions of outsourcing hotel food and beverage services, International Journal of Contemporary Hospitality Management, vol. 12, no. 4, pp. 256-261.

John, G \& Weitz, BA 1988, 'Forward integration into distribution: An empirical test of transaction cost analysis', Journal of Law, Economics and Organization, vol. 4, fall, pp. 337-355.

Klein, S, Frazier, GL \& Roth, VJ 1990, 'A transaction cost analysis model of channel integration in international markets, Journal of marketing research, vol 27, May, 196208.

Kakabadse, N \& Kakabadse, A 2000, 'Critical review - Outsourcing: a paradigm shift'. Journal of Management Development, vol. 19, 8, pp. 670-728.

Lam, T \& Han, M 2005, 'A study of outsourcing strategy: a case involving the hotel industry in Shanghai, China', International Journal of Hospitality Management, vol. 24, 41-56

Lamminmaki, D 2005, 'Why do hotels Outsource? An investigation using asset specificity', International Journal of Contemporary Hospitality Management, vol 17, no. 6, pp. 516-528.

Lamminmaki, D 2007, 'Outsourcing in Australian Hotels: A transaction cost economics perspective', Journal of Hospitality and Tourism Research, vol. 31, no. 1, pp. 73-110.

Langfield-Smith, K \& Smith, D 2003, 'Management control systems and trust in outsourcing relationships', Management Accounting Research, vol. 14, no. 3, pp. 281307.

Levy, D 1985, 'The Transactions Cost Approach to Vertical Integration: An Empirical Examination’, Review of Economics and Statistics, vol. 67, pp. 438-445. 
Liberson, J 1995a, 'The moveable banquet: Mobility of site, staff, and resources just may be the key to profitable banquets and catering'. Lodging, 20 (July): 75-78.

Liberson, J 1995b,. ‘Cooking Up New Kitchens’. Lodging, 20 (October): 69-72.

Mahoney, JT 1992, 'The choice of organizational form; vertical financial ownership versus other modes of vertical integration. Strategic Management Journal, vol. 13, no. 8, pp. 559-584.

Maltz, A 1994, 'Outsourcing the warehousing function: Economic and strategic considerations', Logistics and Transportation Review, vol. 30, September, pp. 245265.

Miles, MB \& Huberman, AM 1994, An expanded sourcebook: Qualitative Data Analysis (Second Edition), Sage, Thousand Oaks, California.

Milgrom, P \& Roberts, J 1992, Economics, Organization and Management, Englewood Cliffs, N.J.

Monteverde, K \& Teece, DJ 1982, 'Supplier Switching Costs and Vertical Integration in the Automobile Industry’, Bell Journal of Economics, vol. 13, pp. 206-213.

Nickerson, JA, Hamilton, BH, \& Wada, T 2001, 'Market position, resource profile, and governance: linking Porter and Williamson in the context of international courier and small package services in Japan', Strategic Management Journal, vol. 22, no. 3, pp. 251-273.

Noordewier, TC, John, G \& Nevin, JR 1990, 'Performance outcomes of purchasing arrangements in industrial buyer-vender relationships, Journal of Marketing, vol 54, October, pp. 80-93.

Osborn RN \& Baughn, CC 1990, 'Forms of interorganizational governance for multinational alliances', Academy of Management Journal, vol. 33, no. 3, pp. 503519.

Paraskevas, A \& Buhalis, D 2002, 'Outsourcing IT for small hotels', Cornell Hotel and Restaurant Administration Quarterly, April, pp. 27-39.

Parmigiani, A 2007, 'Why do firms both make and buy? An investigation of concurrent sourcing’, Strategic Management Journal, vol 28, pp. 285-311.

Palay, T 1984, 'Comparative Institutional Economics: The Governance of Rail Freight Contracting’, The Journal of Legal Studies XIII, June, pp. 265-288.

Pilling, BK, Crosby, LA \& Jackson Jr DW 1994, 'Relational bonds in industrial exchange: An experimental test of the transaction cost economic framework', Journal of Business Research, vol. 30, pp. 237-251. 
Rindfleisch A \& Heide JB 1997, 'Transaction cost analysis: past, present, and future applications, Journal of Marketing, vol 61, pp. 30-54.

Sartorius, K \& Kirsten, J 2005, 'The boundaries of the firm: why do sugar producers outsource sugarcane production?’, Management Accounting Research, vol. 16, pp. 8199.

Seal, W, Cullen, J, Dunlop, A, Berry, T, \& Ahmen, M 1999, 'Enacting a European supply chain: a case study on the role of management accounting', Management Accounting Research, vol. 10, no. 3, pp. 303-322.

Speklé, R 2001, 'Explaining management control structure variety: a transaction cost economics perspective', Accounting, Organizations and Society, vol. 26, no. 4-5, 419441.

Van der Meer-Kooistra, J \& Vosselman, EJ 2000, 'Management control of interfirm transactional relationships: the case of industrial renovation and maintenance', Accounting, Organizations and Society, vol. 25, pp. 51-77.

Venkatraman, $N$ 1997, 'Beyond outsourcing: Manageing IT resources as a value centre’, Sloan Management Review, vol. 38, No. 3, pp. 51-64.

Vosselman, E 2002, 'Towards horizontal archetypes of management control: a transaction cost economics perspective', Management Accounting Research vol. 13, pp. 131-148.

Widener, SK, \& Selto, FH 1999, 'Management Control Systems and Boundaries of the Firm: Why do firms outsource internal auditing activities?', Journal of Management Accounting Research vol. 11, pp. 48-73.

Williamson, OE 1975, Markets and Hierarchies, New York, Free Press.

Williamson, OE 1979, 'Transaction cost economics: the governance of transactional relations', Journal of Law and Economics, October, pp. 233-261.

Williamson, OE 1985, The Economic Institutions of Capitalism: Firms, Markets and Relational Contracting, Free Press, New York.

Williamson, OE 1988, 'The logic of economic organization', Journal of Law Economics and Organisation, vol. 4, no. 1, pp. 65-93.

Williamson, OE 1991, 'Strategizing, Economizing, and Economic Organization', Strategic Management Journal, vol. 12, pp. 75-94.

Williamson, OE 1996, The Mechanisms of Governance, Oxford University Press, New York.

Williamson, OE 1999, 'Strategy Research: Governance and Competence Perspectives’, Strategic Management Journal, vol. 20, no. 12, pp. 1087-1109. 


\begin{tabular}{|c|c|c|c|c|}
\hline & Overview & $\begin{array}{l}\text { ble } 1 \\
\text { otel Intervie }\end{array}$ & & \\
\hline $\begin{array}{l}\text { Interviewee } \\
\text { Reference }^{\mathrm{a}}\end{array}$ & $\begin{array}{c}\text { Position } \\
\text { of Interviewee }\end{array}$ & $\begin{array}{c}\text { Number } \\
\text { of } \\
\text { restaurants }\end{array}$ & $\begin{array}{c}\text { Number } \\
\text { of Rooms }\end{array}$ & Star rating \\
\hline $1-\mathrm{Fca}^{\mathrm{b}}$ & Financial Controller & \multirow{4}{*}{6} & \multirow{4}{*}{609} & \multirow{4}{*}{5} \\
\hline 1-FCb & Financial Controller & & & \\
\hline $1-\mathrm{FB}$ & F\&B Manager & & & \\
\hline 1-PE & Project Engineer & & & \\
\hline 2 & Financial Controller & 5 & 134 & 5 \\
\hline 3 & General Manager & 2 & 298 & $4-1 / 2$ \\
\hline 4 & F\&B Manager & 3 & 350 & 5 \\
\hline $5-\mathrm{FC}$ & Financial Controller & \multirow[b]{2}{*}{5} & \multirow[b]{2}{*}{330} & \multirow[b]{2}{*}{5} \\
\hline 5-GM & General Manager & & & \\
\hline 6 & Financial Controller & 3 & 300 & 5 \\
\hline 7 & Financial Controller & 1 & 302 & $4-1 / 2$ \\
\hline 8 & General Manager & 1 & 405 & 5 \\
\hline 9 & Financial Controller & 2 & 403 & $4-1 / 2$ \\
\hline 10 & Financial Controller & 3 & 205 & 5 \\
\hline 11 & Financial Controller & 1 & 405 & $4-1 / 2$ \\
\hline
\end{tabular}

a Multiple interviewees from one hotel have been differentiated by the inclusion of their title's abbreviation (ie., FC: Financial Controller; GM: General Manager; FB: Food \& Beverage Manager; PE: Project Engineer).

${ }^{\mathrm{b}}$ Hotel 1 provided two Financial Controllers (FC-a and FC-b). 


\begin{tabular}{|c|c|c|}
\hline \multicolumn{2}{|c|}{ Table 2 } \\
\hline Revising TCE's frequency theory \\
\hline Very small activity & $\begin{array}{c}\text { Outsourcing } \\
\text { Implication }\end{array}$ & $\begin{array}{c}\text { Consistency with } \\
\text { TCE model }\end{array}$ \\
\hline Small activity & Insource & Inconsistent \\
\hline Large activity & Outsource & Consistent \\
\hline $\begin{array}{c}\text { Large activity undertaken by group of } \\
\text { organisations (eg., hotel chain) }\end{array}$ & Onsource & Consistent \\
\hline
\end{tabular}




\section{Appraisal of the TCE theory concerning the frequency attribute}

\begin{tabular}{|c|c|}
\hline Hotel Activity & Observations that support / contradict frequency proposition* \\
\hline \multicolumn{2}{|c|}{ Food and Beverage } \\
\hline $\begin{array}{l}\text { Food \& } \\
\text { Beverage in } \\
\text { general }\end{array}$ & - Hotel size deemed biggest factor for insourcing F\&B. (Hotel 4) \\
\hline Banqueting & - $\quad$ Large size warranted insourcing. (Hotel $1 \mathrm{FCa}$ ) \\
\hline $\begin{array}{l}\text { Pre-prepared } \\
\text { ingredients }\end{array}$ & $\begin{array}{l}\text { - Hotel developed centralised kitchens where majority of foods are pre-prepared } \\
\text { (Hotel } 3 \text { GM) } \\
\text { - Many hotels had moved to the outsourcing of pre-prepared ingredients as } \\
\text { specialist suppliers could achieve mass production economies. } \\
\text { - Hotel would like to outsource to reap benefits of economies of scale, but good } \\
\text { supplier not available. (Hotel } 3 \text { GM) }\end{array}$ \\
\hline Bread & - Cannot justify insourcing due to insufficient volume. (Hotel 2 FC) \\
\hline Chocolate & $\begin{array}{l}\text { - Chocolate is a specialised skill and insufficient volume to justify having a person } \\
\text { inhouse. (Hotel 2 FC) }\end{array}$ \\
\hline Pastry & $\begin{array}{l}\text { - Low pastry volume consistently referred to by interviewees as factor driving } \\
\text { decision to outsource. } \\
\text { - } \quad \text { Pasty insourced in largest hotel. (Hotel 1) } \\
\text { - One hotel managed the volume issue by opening a retail pastry shop, and } \\
\text { channelling excess pastry production into retail sales. (Hotel 4) }\end{array}$ \\
\hline \multicolumn{2}{|c|}{ Administration and professional activities } \\
\hline $\begin{array}{l}\text { Computer } \\
\text { support }\end{array}$ & $\begin{array}{l}\text { - Computer support outsourced as insufficient justification for a full time position. } \\
\text { (Hotel 11) }\end{array}$ \\
\hline $\begin{array}{l}\text { Marketing } \\
\text { strategy }\end{array}$ & - Smaller hotels may not have capacity to manage it in house. (Hotel 8) \\
\hline $\begin{array}{l}\text { Customer } \\
\text { Satisfaction } \\
\text { Research }\end{array}$ & $\begin{array}{l}\text { - Generally outsourced by most hotels interviewed. Frequency and specialist } \\
\text { supplier issues were main outsourcing reasons. (Hotel 3) } \\
\text { - "If we hired one or two bodies we would still not have the appropriate cross } \\
\text { section of skills to handle that work." (Hotel } 2 \text { FC) }\end{array}$ \\
\hline $\begin{array}{l}\text { Mergers and } \\
\text { Acquisition }\end{array}$ & $\begin{array}{l}\text { - "If we were Hilton USA, where they are forever on an acquisition path, they } \\
\text { have a mergers and acquisition team in place. I don’t. I do it (mergers) } \\
\text { sporadically and therefore ... subcontract out to someone else” (Hotel } 1 \text { Fca) }\end{array}$ \\
\hline \multicolumn{2}{|c|}{ Cleaning and Maintenance Activities } \\
\hline Housekeeping & $\begin{array}{l}\text { - If occupancy levels are volatile and unpredictable, it makes sense to outsource } \\
\text { occupancy related activities (eg housekeeping), as a specialist supplier has } \\
\text { greater scope to smooth peak demand periods across a larger workforce (Hotel } \\
\text { 9). }\end{array}$ \\
\hline $\begin{array}{l}\text { Carpets and } \\
\text { Window } \\
\text { cleaning }\end{array}$ & $\begin{array}{l}\text { - Most hotels outsourced carpets and window cleaning due to the economies of } \\
\text { scale that a supplier can achieve. } \\
\text { - All hotels maintained an inhouse capacity to complete spontaneously arising, } \\
\text { one-off, small jobs. }\end{array}$ \\
\hline
\end{tabular}




\begin{tabular}{|c|c|}
\hline F\&B cleaning & $\begin{array}{l}\text { - Large in-house housekeeping department warranted insourcing of F\&B cleaning. } \\
\text { (Hotel 4) }\end{array}$ \\
\hline Linen ownership & $\begin{array}{l}\text { - Economies of scale of laundry specialist motivated the decision to outsource } \\
\text { linen ownership. (Hotel 8). }\end{array}$ \\
\hline Gardening & $\begin{array}{l}\text { - Gardening insourced as hotel part of a group of hotels, and sister hotels could } \\
\text { share the full time gardener. (Hotel 11) } \\
\text { - Garden maintenance worth outsourcing if grounds big enough. "Once you start } \\
\text { changing 10-50 plants every month, then you start to outsource". The size of an } \\
\text { activity can be too small to make it worthwhile for a subcontractor to be } \\
\text { involved. }\end{array}$ \\
\hline \multicolumn{2}{|l|}{ Other aspects } \\
\hline $\begin{array}{l}\text { Housekeeping, } \\
\text { Payroll, } \\
\text { Gardening }\end{array}$ & $\begin{array}{l}\text { - As volume increases, after a certain point outsourcing is no longer justifiable. } \\
\text { (Hotel 9) }\end{array}$ \\
\hline Hotel chains & $\begin{array}{l}\text { Enhanced purchasing power of a hotel group resulted in cheaper outsourcing } \\
\text { opportunities. As size increased purchasing power, increased size signifies a } \\
\text { discounted cost of outsourcing. (Hotels } 1,2,3,6,7,11 \text { ) }\end{array}$ \\
\hline $\begin{array}{l}\text { Outsourcing in } \\
\text { general }\end{array}$ & $\begin{array}{l}\text { - } \quad \text { Many interviewees saw frequency as relevant to outsourcing decisions. } \\
\text { - } \quad \text { Significant size of specialist supplier can warrant outsourcing. (Hotel } 1 \text { FCa) }\end{array}$ \\
\hline
\end{tabular}

* Observations supporting TCE theory are presented in plain type, observations contradicting the theory are in italics. 


\section{Table 4 \\ Appraisal of the TCE theory concerning the uncertainty attribute}

\begin{tabular}{|c|c|}
\hline Hotel Activity & Observations that support / contradict uncertainty proposition* \\
\hline $\begin{array}{l}\text { Food and } \\
\text { Beverage }\end{array}$ & $\begin{array}{l}\text { - Most interviewees felt F\&B is insourced to deal with instability, unpredictability, } \\
\text { complexity and control issues. } \\
\text { - There are many activities involved in F\&B, and many can go wrong. No } \\
\text { contract can provide the same control as insourcing. (Hotel } 8 \mathrm{GM} \text { ) } \\
\text { - F\&B is challenging and provides low profit margins, but it is too important to } \\
\text { contract out. (Hotel 9 FC) }\end{array}$ \\
\hline $\begin{array}{l}\text { Public area } \\
\text { cleaning }\end{array}$ & $\begin{array}{l}\text { - Difficulty in contracting due to job variability. This prevented Hotel 5's GM } \\
\text { from outsourcing. } \\
\text { - Stable and an easy area to contract for. (Hotel 9 FC) }\end{array}$ \\
\hline Gardening & $\begin{array}{l}\text { - Difficult to outsource due to the problems of ensuring the work is completed } \\
\text { satisfactorily (behavioural uncertainty). (Hotels } 5 \text { and 12) }\end{array}$ \\
\hline $\begin{array}{l}\text { Outsourcing in } \\
\text { general }\end{array}$ & $\begin{array}{l}\text { - Most managers felt that if a hotel is not satisfied with performance, it is easier to } \\
\text { manage a change in the behaviour of an inhouse employee, than to renegotiate } \\
\text { with a supplier. } \\
\text { - Prefer to outsource where there is specialised work or specialised equipment } \\
\text { (Hotel } 8 \text { GM). Constantly having to retrain and upgrade highlights behavioural } \\
\text { and environmental uncertainty } \\
\text { - Fast evolving fields can give rise to increased insourcing. }\end{array}$ \\
\hline
\end{tabular}

* Observations supporting TCE theory are presented in plain type, observations contradicting the theory are in italics. 